\title{
Corrigendum: The Sweet Taste of Adapting to the Desert: Fructan Metabolism in Agave Species
}

\author{
Arely V. Pérez-López and June Simpson* \\ Department of Genetic Engineering, Cinvestav Unidad Irapuato, Guanajuato, Mexico
}

Keywords: Agavaceae, agavins, signaling, metabolism, adaptation

\section{A Corrigendum on}

The Sweet Taste of Adapting to the Desert: Fructan Metabolism in Agave Species

by Pérez-López, A. V., and Simpson, J. (2020). Front. Plant Sci. 11:324. doi: 10.3389/fpls.2020.00324

OPEN ACCESS

Approved by:

Frontiers Editorial Office,

Frontiers Media SA, Switzerland

${ }^{*}$ Correspondence: June Simpson

june.simpson@cinvestav.mx

Specialty section:

This article was submitted to Crop and Product Physiology,

a section of the journal

Frontiers in Plant Science

Received: 23 April 2020

Accepted: 28 April 2020

Published: 28 May 2020

Citation:

Pérez-López AV and Simpson $J$ (2020) Corrigendum: The Sweet Taste

of Adapting to the Desert: Fructan

Metabolism in Agave Species.

Front. Plant Sci. 11:659.

doi: $10.3389 /$ fpls.2020.00659
In the original article, there was a mistake in the legend of Figure 1. The correct legend appears below.

"Figure 1. Schematic representation of plant fructans, their structural diversity and the enzymes involved in their metabolism. (A) linear inulin and (B) levan, (C) branched graminan, (D) neo-inulin, (E) neo-levan and (F) highly branched agavin. Gray-glucose, green-fructose, gray shadow-sucrose moiety. Blue rectangles-enzymes:1-SST-sucrose:sucrose1-fructosyltransferase, 1-FFT-fructan:fructan1-fructosyltransferase, 6-SFT-sucrose:fructan 6-fructosyltransferase, 6G-FFT-fructan:fructan 6G fructosyltransferase, $\mathrm{FEH}$-fructan exohydrolase. Red text-dicotyledons, Black text-monocotyledons."

In addition, the error in the legend of Figure 1 was carried over into the text as the word "pentose" should have been removed. A correction has been made to the Introduction, paragraph 3:

"Fructans are an alternative to starch for long-term carbohydrate storage. Starch, composed of linear amylose or branched amylopectin glucose (hexose) polymers, accumulates in chloroplasts, whereas fructans produced by adding fructose monomers to sucrose are stored in vacuoles. Fructans are structurally flexible, highly soluble, accumulate to high levels, and have the ability to associate with cell membranes (Van den Ende, 2013). These properties are intrinsic to their roles in response to stress (Versluys et al., 2018) or developmental signals (Bolouri Moghaddam and Van den Ende, 2013). Fructans are exploited commercially as a replacement for sugar or fats, as fiber or prebiotics (Vijn and Smeekens, 1999) and have useful properties for drug delivery and cryoprotection (Audouy et al., 2011; Gupta et al., 2019)."

The authors apologize for this error and state that this does not change the scientific conclusions of the article in any way. The original article has been updated. 


\section{REFERENCES}

Audouy, S. A., Van Der Schaaf, G., Hinrichs, W. L., Frijlink, H. W., Wilschut, J., and Huckriede, A. (2011). Development of a dried influenza whole inactivated virus vaccine for pulmonary immunization. Vaccine 29, 4345-4352. doi: 10.1016/j.vaccine.2011.04.029

Bolouri Moghaddam, M. R., and Van den Ende, W. (2013). Sugars, the clock and transition to flowering. Front. Plant Sci. 4:22. doi: 10.3389/fpls.2013.00022

Gupta, N., Jangid, A. K., Pooja, D., and Kulhari, H. (2019). Inulin: a novel and stretchy polysaccharide tool for biomedical and nutritional applications. Int. J. Biol. Macromol. 132, 852-863. doi: 10.1016/j.ijbiomac.2019.03.188

Van den Ende, W. (2013). Multifunctional fructans and raffinose family oligosaccharides. Front. Plant Sci. 4:247. doi: 10.3389/fpls.2013.00247
Versluys, M., Kirtel, O., Toksoy Oner, E., and Van den Ende, W. (2018). The fructan syndrome: evolutionary aspects and common themes among plants and microbes. Plant Cell Environ. 41, 16-38. doi: 10.1111/pce.13070

Vijn, I., and Smeekens, S. (1999). Fructan: more than a reserve carbohydrate? Plant Physiol. 120, 351-360.

Copyright (c) 2020 Pérez-López and Simpson. This is an open-access article distributed under the terms of the Creative Commons Attribution License (CC BY).

The use, distribution or reproduction in other forums is permitted, provided the original author(s) and the copyright owner(s) are credited and that the original publication in this journal is cited, in accordance with accepted academic practice. No use, distribution or reproduction is permitted which does not comply with these terms. 